\title{
A FOLLOW-UP STUDY OF THE OCCUPATIONAL HAND ECZEMA AND SKIN DAMAGE RISK IN HEALTHCARE PROVIDERS FROM ROMANIA IN TIME OF COVID-19
}

\author{
ANCA E. CHIRIAC ${ }^{1}$, ADINA COROABA ${ }^{2}$, ANCA CHIRIAC $^{3}$, MARIANA PINTEALA ${ }^{2}$, \\ LENUȚA PROFIRE $^{4 *}$, BIANCA PROFIRE ${ }^{1}$, DOINA AZOICĂI ${ }^{1}$ \\ 1 "Grigore T. Popa” University of Medicine and Pharmacy, Faculty of Medicine, 16 Universității Street, Iași, Romania \\ ${ }^{2}$ Centre of Advanced Research in Bionanoconjugates and Biopolymers, "Petru Poni" Institute of Macromolecular \\ Chemistry, 41 A Grigore Ghica Vodă Street, Iași, Romania \\ ${ }^{3}$ Apollonia University, Nicolina Medical Centre, Department of Dermatology, 3 Hatman Sendrea Street, Iași, Romania \\ 4 “Grigore T. Popa” University of Medicine and Pharmacy, Faculty of Pharmacy, 16 Universității Street, Iași, Romania
}

*corresponding author: lenuta.profire@umfiasi.ro

Manuscript received: May 2020

\begin{abstract}
The aim of this work was to estimate the prevalence and risk factors of self-reported, work-related occupational hand eczema, targeting personnel working in hospitals and ambulatory units throughout Romania. A standardized questionnaire was specifically addressed to healthcare professionals from different medical fields. Out of 245 healthcare providers who took part in the survey, $161(65.71 \%)$ were nurses, and 235 (95.92) women, which confirms that women are prevalent in this working sector. The latex powder-gloves were the most frequently implied trigger factor, $223(91.02 \%)$ responders reported the daily use of protective gloves and $37(15.12 \%)$ of them have reported the protective gloves as a possible cause for skin lesions. Also, an important part of responders testified a prolonged contact with water, which confirms the importance of wet environment in inducing occupational hand eczema. In addition, X-ray photoelectron spectroscopy (XPS) analysis of powder free latex gloves was performed in order to establish a correlation between the elemental composition and risk factors for hand eczema. The results support the implication of $\mathrm{Cd}$ and $\mathrm{Ca}$, which were detected on the inner faces of the gloves, to the toxicity to the skin.
\end{abstract}

\section{Rezumat}

Obiectivul studiului a fost de a estima prevalența și factorii de risc asociați eczemelor de contact profesionale, raportate de personalul medical din spitalele și unitățile ambulatorii din România. Un chestionar standard a fost adresat personalului medical din diferite specialități. Din cele 245 de cadre medicale care au participat la studiu, $161(65,71 \%)$ au fost infirmiere și $235(95,92 \%)$ femei, ceea ce confirmă faptul că femeile sunt predominante în acest sector de activitate. Mănușile din latex pudrate au fost cel mai incriminat factor declanșator, $223(91,02 \%)$ respondenți raportând folosirea zilnică a mănușilor, iar 37 $(15,12 \%)$ dintre ei au raportat mănuşile ca posibilă cauză a leziunilor cutanate. Totodată o pondere importantă a respondenților au raportat un contact prelungit cu apa, ceea ce confirmă importanța mediului umed în apariţia eczemelor de contact profesionale. În plus, s-a efectuat analiza spectroscopică fotoelectronică cu raze X (XPS) a mănușilor din latex pentru a stabili o corelație între compozitia elementală și factorii de risc pentru eczema de contact. Rezultatele susțin implicarea $\mathrm{Cd}$ și $\mathrm{Ca}$, care au fost detectate pe suprafața internă a mănușilor, în toxicitatea la nivel cutanat.

Keywords: COVID-19, hand eczema, gloves, healthcare providers, X-ray photoelectron spectroscopy

\section{Introduction}

Occupational skin diseases should be a public health priority since they represent up to $30 \%$ of occupational diseases [2]. In addition, skin diseases have a significant socio-economic impact on each individual therefore exposure assessment is essential in order to prevent, diagnose and treat work-related or occupational skin diseases; in order to achieve this, a precise type of occupational/professional anamnesis is required. Occupational contact dermatitis, mostly hand eczema (which accounts for $80 \%$ of all occupational skin diseases) has a great impact on the quality of life and professional activity of healthcare providers [7].
Early diagnosis and appropriate protective measures are essential in order to prevent the progression to chronic eczema, which is much more difficult to treat [7].

Moreover, as a consequence of SARS-CoV-2 pandemic, the most important recommendations for infection prevention are hand hygiene and surface decontamination. Hand hygiene is achieved by frequent hand washing with soap and water for at least $20 \mathrm{sec}$, use of $60 \%$ alcohol hand sanitizers and wearing gloves [16]. The healthcare providers are most exposure to skin damage due to high exposure to wet environment and chemical agents, mainly disinfectants. As result, skin dryness, 
irritant contact dermatitis and allergic contact dermatitis have been reported. For example, in Hubei, China, the hand eczema was reported by more than $76 \%$ of healthcare providers which washed their hands more than 10 times/day and wear gloves all time at work [6]. The aim of the study was to obtain data on hand eczema and risk factors from healthcare providers working in hospitals and ambulatory units from multiple departments, in different cities from Romania, including in time of COVID-19. The study was based on a self-reported questionnaire addressed to employees from all medical units and focussed on hand eczema, trigger factors and protective measures. Powder free latex gloves were examined using X-ray photoelectron spectroscopy (XPS) method with the purpose of establishing a correlation between qualitative and quantitative elemental composition with respect to hand eczema risk factors.

\section{Materials and Methods}

\section{The questionnaire}

The questionnaire was anonymous, easy to understand, with yes or no answers to specific questions, and focused on the clinical aspects related to direct exposure. Work-related aggravating factors such as: contact with chemical agents, the use of latex gloves or different types of gloves, other suggestive exposures and hand washing frequency, were considered.

$X$-ray photoelectron spectroscopy (XPS) analysis Three different brands of powder free latex gloves (noted as sample 1, 2 and 3) were analysed in order to establish their elemental composition. The inner surface from three distinct areas of each glove was analysed: one area from the index finger and two different areas from the palm. XPS analysis was performed with a KRATOS AXIS Nova spectrometer equipped with an aluminium $\mathrm{K} \alpha \mathrm{X}$-ray source operated at $150 \mathrm{~W}(15 \mathrm{kV} \times 10 \mathrm{~mA})$. XPS wide scans were collected in the range of $-10 \div 1200 \mathrm{eV}$ with a resolution of $1 \mathrm{eV}$ and a pass energy of $160 \mathrm{eV}$. Data was analysed using Vision Processing software (Vision2 software, Version 2.2.10).

\section{Results and Discussion}

\section{Analysis of questionnaires}

A total of 1000 questionnaires were distributed to hospitals and ambulatory units from main cities in Romania and medical personnel from all departments took part in this study. Only 245 questionnaires were validated, which means a positive response rate of $24.50 \%$, in contrast with other similar studies $(65 \%$ in a study performed in Denmark in 2007) [4]. This relatively small percentage suggests that the prevalence of occupational or work related hand eczema among healthcare providers (from the entire country) is highly underestimated. Some possible reasons for the low participation to the study could be: the indifference to the subject, the lack of compliance or knowledge, the unwillingness to recognize existing symptoms and the fear that correct answers can affect daily activity or even lead to participants losing their job. Out of the 245 questionnaire responders, $83(33.88 \%)$ were care takers and $161(65.71 \%)$ were nurses. Physicians did not want to take part to the study with only one questionnaire being ratified by a surgeon. The great majority $(95.92 \%, 235$ out of 245$)$ of questionnaires confirmed that women are prevalent in this working sector.

Referring to the age of the responders (Figure 1), statistical analysis revealed a higher frequency of hand eczema reported by healthcare providers older than 40 years when compared to younger than 40 years.

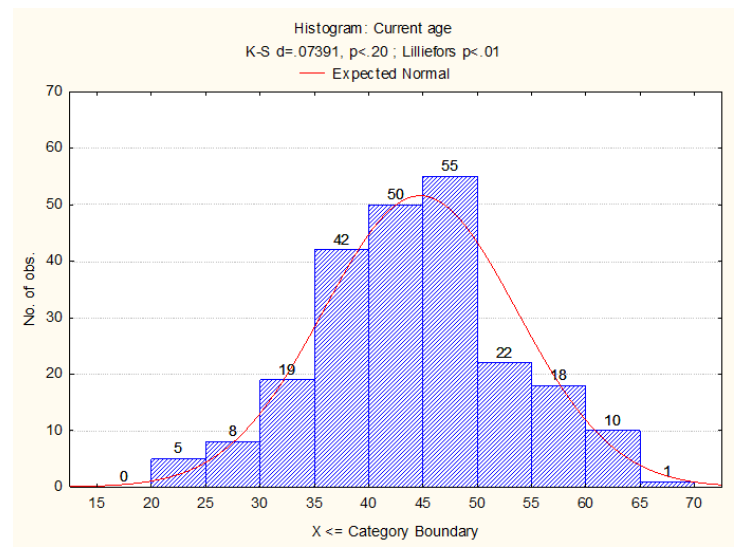

Figure 1.

Age distribution of the responders

Regarding the timing of when respondents have eczema, $18(7.34 \%)$ reported having hand eczema at the time of the study, $19(7.75 \%)$ within the previous 3 months, $12(4.89 \%)$ within 12 months and $29(11.83 \%)$ reported having hand eczema for over a year prior to the study. Out of 245 of respondents, $223(91.02 \%)$ reported the daily use of protective gloves; only $37(15.12 \%)$ of participants incriminated protective gloves as a possible cause for skin lesions, the majority of responders did not answer to the question (Table I). When asked, the majority of healthcare workers reported latex gloves with powder were most commonly used for their daily practice, as seen in Table II. Severe case of allergic contact dermatitis was reported also by healthcare providers in time of COVID-19 (Figure 2).

Table I

Gloves as a cause of skin problems-symptoms: selfevaluation

\begin{tabular}{|l|c|c|}
\hline \multicolumn{1}{|c|}{ Gloves } & $\begin{array}{c}\text { Responders } \\
\text { (no.) }\end{array}$ & $\begin{array}{c}\text { Percentage } \\
(\mathbf{\%})\end{array}$ \\
\hline $\mathrm{Y}=$ Yes & 37 & 15.10 \\
\hline $\mathrm{N}=$ No & 10 & 4.08 \\
\hline $\mathrm{D}=$ Deny & 1 & 0.41 \\
\hline Missing answer & 197 & 80.41 \\
\hline Total & $\mathbf{2 4 5}$ & $\mathbf{1 0 0}$ \\
\hline
\end{tabular}


FARMACIA, 2020, Vol. 68, 4

\section{Table II}

Type of gloves used at work

\begin{tabular}{|l|c|c|}
\hline \multicolumn{1}{|c|}{ Type of gloves } & $\begin{array}{c}\text { Responders } \\
\text { (no.) }\end{array}$ & $\begin{array}{c}\text { Percentage } \\
(\mathbf{\%})\end{array}$ \\
\hline Latex, powder & 204 & 83.30 \\
\hline Latex, no powder & 41 & 16.70 \\
\hline Total & $\mathbf{2 4 5}$ & $\mathbf{1 0 0}$ \\
\hline
\end{tabular}

Table III

Other incriminated agents at work

\begin{tabular}{|l|c|c|}
\hline \multicolumn{1}{|c|}{ Type of agent } & $\begin{array}{c}\text { Responders } \\
\text { (no.) }\end{array}$ & $\begin{array}{c}\text { Percentage } \\
(\mathbf{\%})\end{array}$ \\
\hline Detergents & 7 & 2.86 \\
\hline Soap & 6 & 2.45 \\
\hline Kallas ${ }^{\circledR}$ & 5 & 2.04 \\
\hline Talc & 5 & 2.04 \\
\hline Cloramine & 1 & 0.41 \\
\hline Clorhexidine & 1 & 0.41 \\
\hline Missing answers & 220 & 89.79 \\
\hline Total & $\mathbf{2 4 5}$ & 100 \\
\hline
\end{tabular}

Table III presents other incriminated agents at work. Kallas $^{\circledR}$ is a very used cleaning product labelled by responders, while talc, the white powder usually found in gloves, was reported separately from gloves.

Other items from the questionnaire were about the frequency of hand washing and the concept of "wet hands", defined by prolonged contact with water (min per day) with or without protective measures. Hand washing was quantified as: permanent (more than 20 times/day) by 192 (78.36\%) of responders, frequently (11 - 20 times/day) by $31(12.65 \%)$ of responders, usually (6 - 10 times/day) by 10 (4.08\%) of responders and as rare ( 0 - 5 times/day) by $3(1.22 \%)$ of responders (Table IV).

Table IV

Frequency of hand washing

\begin{tabular}{|l|c|c|}
\hline Hand washing/day & $\begin{array}{c}\text { Responders } \\
\text { (no.) }\end{array}$ & $\begin{array}{c}\text { Percentage } \\
(\mathbf{\%})\end{array}$ \\
\hline Permanently (> 20) & 192 & 78.36 \\
\hline Frequently (11 - 20) & 31 & 12.65 \\
\hline Usually (6 - 10) & 10 & 4.08 \\
\hline Rare (0 - 5) & 3 & 1.22 \\
\hline Missing responses & 9 & 3.69 \\
\hline Total & $\mathbf{2 4 5}$ & $\mathbf{1 0 0}$ \\
\hline
\end{tabular}
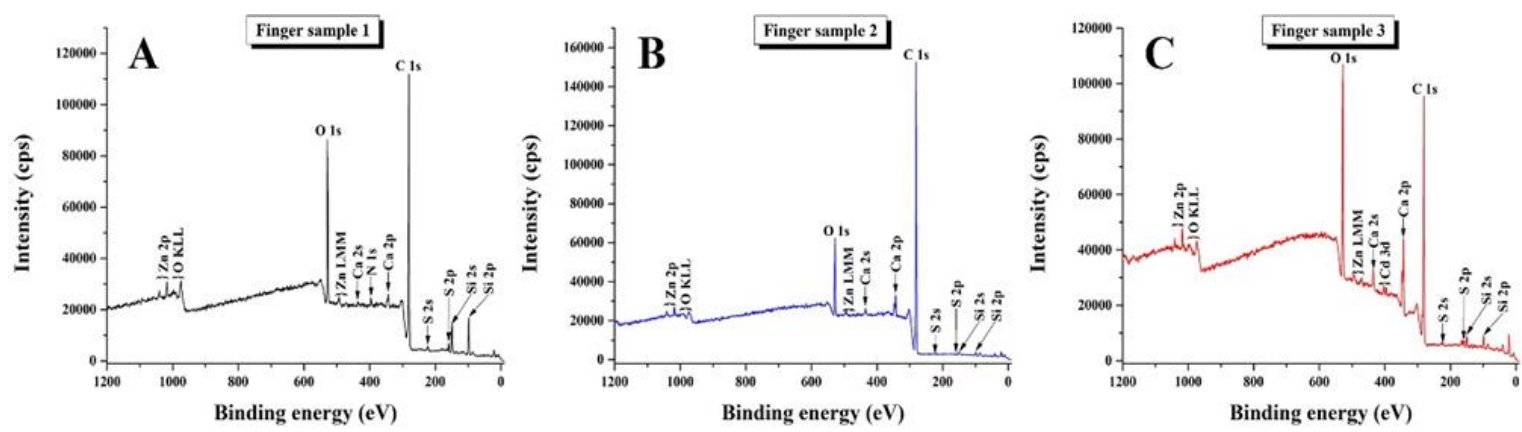

Figure 2.
An important part of responders testified a prolonged contact with water, which confirms the importance of wet environment in inducing occupational hand eczema, the details are presented in Table V.

Table V

"Wet hands" defined as the contact with water of each responder, how many minutes/day

\begin{tabular}{|l|c|c|}
\hline \multicolumn{1}{|c|}{ Min/day } & $\begin{array}{c}\text { Responders } \\
\text { (no.) }\end{array}$ & $\begin{array}{c}\text { Percentage } \\
(\mathbf{\%})\end{array}$ \\
\hline Frequently $(>120)$ & 66 & 24.53 \\
\hline Often $(30-120)$ & 56 & 22.85 \\
\hline Rare $(<30)$ & 105 & 42.86 \\
\hline Missing answers & 18 & 9.76 \\
\hline Total & $\mathbf{2 4 5}$ & $\mathbf{1 0 0}$ \\
\hline
\end{tabular}

When compared to clinical examination, the validity of questionnaires is debatable even though it allows an anonymous investigation on a larger scale, a non-homogenous study population and collection of variable additional data. Self-reported eczema study has been used and the results have been validated in many studies [10, 13]; several Swedish studies were based on self-reported occupational hand eczema and have shown a sensitivity of $87 \%$ and specificity of $79 \%$ [10].

The present study confirms the frequency of occupational hand eczema, especially in female nurses; this result is in concordance with other reports in which $70-72 \%$ of occupational skin disorders have been diagnosed in nurses [11]. Compared to other similar studies, the present study indicates a higher positive rate of responders among women over 40 years old, which is in contrast to other reports [8].

$X$-ray photoelectron spectroscopy (XPS) analysis

$\mathrm{X}$-ray photoelectron spectroscopy (XPS) is a noninvasive quantitative and qualitative surface technique (sampling depth $\leq 10 \mathrm{~nm}$ ) that can detect elements, with the exception of hydrogen and helium. XPS can also provide information regarding metal oxidation states, chemical bonding, and general types of organic functional groups [15]. This technique can be used to identify the elemental concentration and characterize the molecular structure of various solid samples [1, $3,12]$.

XPS wide scans for the inner surfaces of 3 latex powder free gloves - finger samples 

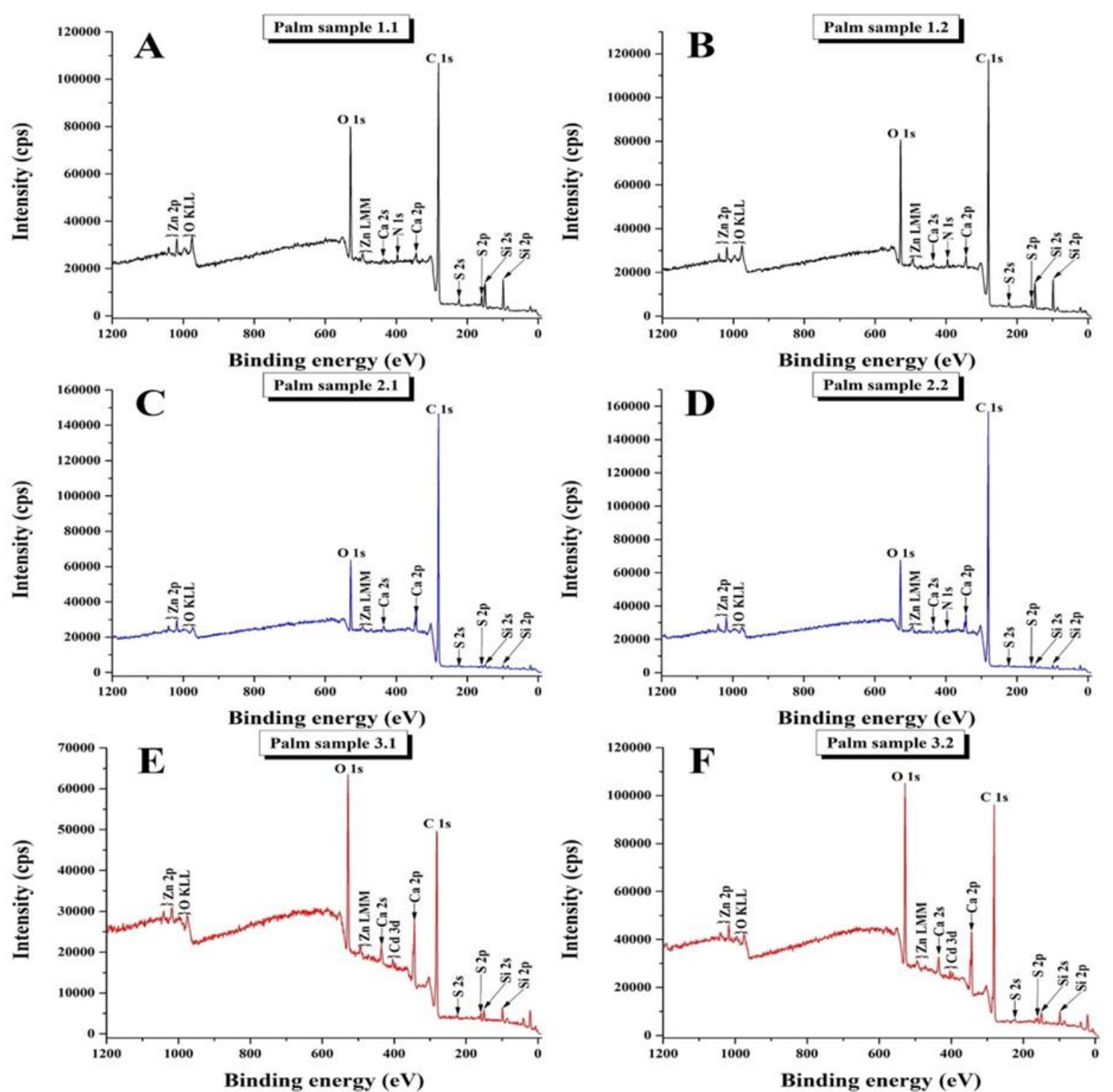

Figure 3.

XPS wide scans for the inner surfaces of 3 latex powder free gloves - palm samples

Wide XPS scans allowed the qualitative and quantitative elemental characterization of the surfaces of the powder free latex gloves; the elements detected on the surfaces included C, N, O, Zn, Ca, S, Si, and Cd (Figures 2 and 3).
From Tables VI and VII, besides the rubber polymer components, it can be clearly seen from XPS results that silicones and other compounds containing $\mathrm{O}$, $\mathrm{Ca}, \mathrm{S}, \mathrm{Cd}$, and $\mathrm{Zn}$ were also present on the inner surfaces of gloves.

Table VI

Surface composition, atomic concentration (\%) determined from the XPS wide scans for the inner surfaces of 3 latex powder free gloves - finger samples

\begin{tabular}{|c|c|c|c|}
\hline \multirow{2}{*}{ Element } & Sample 1 & Sample 2 & Sample 3 \\
\cline { 2 - 4 } & Atomic conc (\%) & Atomic conc (\%) & Atomic conc (\%) \\
\hline $\mathbf{Z n}$ & 0.66 & 0.37 & 1.37 \\
\hline $\mathbf{O}$ & 17.66 & 9.95 & 24.29 \\
\hline $\mathbf{N}$ & 1.76 & nd & $\mathrm{Nd}$ \\
\hline $\mathbf{C a}$ & 1.22 & 1.81 & 5.01 \\
\hline $\mathbf{C}$ & 70.88 & 86.69 & 65.50 \\
\hline $\mathbf{S}$ & 0.79 & 0.22 & 0.59 \\
\hline $\mathbf{S i}$ & 7.03 & 0.97 & 2.97 \\
\hline $\mathbf{C d}$ & $\mathrm{nd}$ & $\mathrm{nd}$ & 0.26 \\
\hline
\end{tabular}

nd $=$ not detected 
FARMACIA, 2020, Vol. 68, 4

All these elements were also found by other studies that implied the analysis through XPS on different types of gloves and have been proven to be contaminants $[5,8,9]$. In the article published by Strohmeier et al. it was demonstrated that many of the glove surface components could easily be transferred to other surfaces when only lightly touched [9]. In this respect, we may assume that these contaminants together with the trigger factors could provoke different types of allergies, including hand eczema. In addition, at a closer introspection, it can be seen that differences were found in the surface compositions between different brands of powder free latex gloves (Tables VI and VII). This could be most likely due the combination of different latex rubber formulas used by the manufacturers, differences in processing conditions, and the use of different surface coatings [9].

Surface composition, atomic concentration (\%) determined from the XPS wide scans for the inner surfaces of 3 latex powder free gloves - palm samples

\begin{tabular}{|c|c|c|c|c|c|c|c|c|c|c|c|c|}
\hline \multirow{3}{*}{ Element } & \multicolumn{4}{|c|}{ Sample 1 (S1) } & \multicolumn{4}{|c|}{ Sample 2 (S2) } & \multicolumn{4}{|c|}{ Sample 3 (S3) } \\
\hline & \multicolumn{2}{|c|}{ Atomic conc $(\%)$} & \multirow{2}{*}{ Mean } & \multirow{2}{*}{ S.D. } & \multicolumn{2}{|c|}{ Atomic conc (\%) } & \multirow{2}{*}{ Mean } & \multirow{2}{*}{ S.D. } & Atomi & conc (\%) & \multirow{2}{*}{ Mean } & \multirow{2}{*}{ S.D. } \\
\hline & $\mathrm{S} 1.1$ & $\mathrm{~S} 1.2$ & & & $\mathrm{~S} 2.1$ & S2.2 & & & S3.1 & S3.2 & & \\
\hline Zn & 0.68 & 0.74 & 0.71 & 0.042 & 0.53 & 0.56 & 0.545 & 0.021 & 1.30 & 0.85 & 1.075 & 0.318 \\
\hline $\mathbf{O}$ & 17.22 & 16.52 & 16.87 & 0.495 & 10.16 & 10.26 & 10.21 & 0.071 & 23.51 & 23.28 & 23.40 & 0.163 \\
\hline $\mathbf{N}$ & 1.36 & 1.99 & 1.675 & 0.446 & nd & 1.29 & - & - & 0.27 & nd & - & - \\
\hline $\mathbf{C a}$ & 0.95 & 0.94 & 0.945 & 0.007 & 1.79 & 1.55 & 1.67 & 0.170 & 5.16 & 4.79 & 4.975 & 0.262 \\
\hline $\mathbf{C}$ & 72.10 & 71.45 & 71.77 & 0.460 & 86.05 & 84.82 & 85.44 & 0.870 & 66.80 & 67.05 & 66.93 & 0.177 \\
\hline $\mathbf{S}$ & 1.19 & 1.05 & 1.12 & 0.099 & 0.35 & 0.32 & 0.335 & 0.021 & 0.19 & 0.62 & 0.405 & 0.304 \\
\hline $\mathbf{S i}$ & 6.51 & 7.31 & 6.91 & 0.566 & 1.12 & 1.20 & 1.16 & 0.057 & 2.77 & 3.21 & 2.990 & 0.311 \\
\hline Cd & nd & nd & nd & nd & nd & nd & nd & nd & 0.27 & 0.22 & 0.245 & 0.035 \\
\hline
\end{tabular}

nd $=$ not detected $;$ S.D. $=$ standard deviation

Animal experimental models on mice showed that Cdinhibits fibroblast proliferation and intensifies cellular apoptosis and thus has a toxic effect when in contact with skin; this effect is dependent of dose and exposure duration [14]. Furthermore, mitochondrial dysfunction and apoptosis were also demonstrated to be influenced by modified $\mathrm{Ca}$ homeostasis [14].

\section{Conclusions}

To the best of our knowledge, data on the incidence of occupational hand eczema in healthcare providers has not been published in Eastern Europe. This study is based on 245 validated anonymous questionnaires, filled by healthcare providers from hospitals and ambulatory units from different cities in Romania. Although the questionnaires were filled in anonymity, we consider that the results could have been influenced by the lack of confidence and anxiety of risking employment. The protective gloves, the use of cleaning agents and hand washing, although part of the prevention protocols, proved to be risk factors for occupational hand eczema, latex powder-gloves being the most frequently implied trigger factor. X-ray photoelectron spectroscopy (XPS) performed on latex gloves showed the presence of $\mathrm{Cd}$, which stimulates skin fibroblast apoptosis in mice by affecting intracellular homeostasis. The results of XPS analysis support the importance of finding $\mathrm{Cd}$ and also $\mathrm{Ca}$ on the inner faces of the gloves which contributing to the toxicity to the skin. Occupational contact dermatitis varies in definition and statistics between European countries and Romania, making challenging comparative statistics. Recognition of occupational skin diseases is important for achieving international guideline, in order to improve prevention and patient management.

\section{Conflict of interest}

The authors declare no conflict of interest.

\section{References}

1. Coroaba A, Pinteala T, Chiriac A, Chiriac AE, Simionescu BC, Pinteala M, Degradation Mechanism Induced by Psoriasis in Human Fingernails: A Different Approach. J Invest Dermatol., 2016; 136(1): 311-313.

2. De Craecker W, Roskams N, Op de Beek R (European Agency for Safety and Health at Work), Occupational skin diseases and dermal exposure in the European Union (EU-25): policy and practice overview. Belgium: European Risk Observatory Report; 2008, http://osha.europa.eu/en/publications/reports/TE70 07049ENC_skin_diseases.

3. Durdureanu-Angheluta A, Uritu CM, Coroaba A, Minea B, Doroftei F, Calin M, Maier SS, Pinteala M, Simionescu M, Simionescu BC, Heparin-anthranoid conjugates associated with nanomagnetite particles and their cytotoxic effect on cancer cells. J Biomed Nanotechnol., 2014; 10(1): 131-142.

4. Flyvholm MA, Bach B, Rose M, Jepsen KF, Selfreported hand eczema in a hospital population. Contact Dermatitis, 2007; 57(2): 110-115.

5. Garçon M, Sauzéat L, Carlson RW, Shirey SB, Simon M, Balter V, Boyet M, Nitrile, latex, neoprene and vinyl gloves: a primary source of contamination for trace element and $\mathrm{Zn}$ isotopic analyses in geological and biological samples. Geostand. Geoanal Res., 2017; 41(3): 367-380

6. Lan J, Song Z, Miao X, Li H, Li Y, Dong L, Yang J, An X, Zhang Y, Yang L, Zhou N, Yang L, Li J, Cao J, Wang J, Tao J, Skin damage among health 
care workers managing coronavirus disease-2019. $J$ Am Acad Dermatol., 2020; 82(5): 1215-1216.

7. Silvestre Salvador JF, Heras Mendaza F, Hervella Garcés M, Palacios-Martínez D, Sánchez Camacho R, Senan Sanz R, Apellaniz González A, GiménezArnau AM, Guidelines for the diagnosis, treatment, and prevention of hand eczema. Actas Dermosifiliogr., 2020; 111(1): 26-40.

8. Strauss RM, Gawkrodger DJ, Occupational contact dermatitis in nurses with hand eczema. Contact Dermatitis, 2001; 44(5): 293-296.

9. Strohmeier BR, Piasecki JD, Plasencia A, XPS surface characterization of disposable laboratory gloves and the transfer of glove components to other surfaces. Spectroscopy, 2012; 27(7): 36-44.

10. Svensson A, Lindberg M, Meding B, Sundberg K, Stenberg B, Self-reported hand eczema: symptombased reports do not increase the validity of diagnosis. Br J Dermatol., 2002; 147(2): 281-284.

11. Taimela S, Laara E, Malmivaara A, Tiekso J, Sintonen $\mathrm{H}$, Justen S, Aro T, Self-reported health problems and sickness absence in different age groups predominantly engaged in physical work. Occup Environ Med., 2007; 64(11): 739-746.

12. Topală T, Bodoki AE, Hangan A, Gheorghe-Cetean S, Oprean L, Revisiting therapeutic sulfonamides in the attempt to improve the antimicrobial properties through metal-ion coordination. Farmacia, 2019; 67(5): 749-758.

13. Vermeulen R, Kromhout H, Bruynzeel DP, de Boer EM, Ascertainment of hand dermatitis using a symptombased questionnaire; applicability in an industrial population. Contact Dermatitis, 2000; 42(4): 202-206.

14. Wang H, Yu Y, Li J, Wu H, Sun J, Zhang Z, Geng L, Yu X, Liu Z, Cadmium stimulates mouse skin fibroblast apoptosis by affecting intracellular homeostasis. Drug Chem Toxicol., 2017; 40(1): 74-84.

15. Watts JF, Wolsetnholme J, An Introduction to Surface Analysis by XPS and AES, John Wiley \& Sons Ltd, Chichester, West Sussex, England, 2003.

16. *** Centers for Disease Control and Prevention Coronavirus Disease 2019 (COVID-2019). How to protect yourself \& others, 2020, www.cdc.gov/ coronavirus/2019-ncov/prepare/prevention.html. 